\title{
Organic matter accumulation and degradation in subsurface coastal sediments: a model-based comparison of rapid sedimentation and aquifer transport
}

\author{
J. M. Holstein ${ }^{1}$ and K. W. Wirtz ${ }^{2}$ \\ ${ }^{1}$ Institute for Chemistry and Biology of the Marine Environment (ICBM), University of Oldenburg, \\ P.O. Box 2503, 26111 Oldenburg, Germany \\ ${ }^{2}$ Institute for Coastal Research, GKSS Research Center, 21502 Geesthacht, Germany
}

Received: 1 March 2010 - Published in Biogeosciences Discuss.: 23 March 2010

Revised: 1 October 2010 - Accepted: 10 November 2010 - Published: 22 November 2010

\begin{abstract}
The redox succession in shallow marine sediments generally exhibits a predictable pattern. Pore water profiles from a back barrier tidal flat in the German Wadden Sea depart from the expected redox zoning. Instead, a sulfate minimum zone associated with a sulfate-methane-sulfate double interface and a distinct ammonium peak at $1.5 \mathrm{~m}$ below sea floor (mbsf) is displayed. Such evidence for significant degradation of organic matter $(\mathrm{OM})$ in subsurface layers is challenging our understanding of tidal flat biogeochemistry as little is known about processes that relocate reactive OM into layers far distant from the sediment-water interface. The objectives of our model study were to identify possible mechanisms for the rapid transport of organic matter to subsurface layers that cause the reversed redox succession and to constrain several important biogeochemical control parameters. We compared two scenarios for OM transfer: rapid sedimentation and burial of $\mathrm{OM}$ as well as lateral advection of suspended POM. Using a diagenetic model, uncertain process parameters, in particular those connected to OM degradation and (vertical or lateral) transport, are systematically calibrated using field data.

We found that both scenarios, advection and sedimentation, had solutions consistent with the observed pore water profiles. For this specific site, however, advective transport of particulate material had to be rejected since the reconstructed boundary conditions were rather improbable. In the alternative deposition set-up, model simulations suggested the deposition of the source OM about $60 \mathrm{yrs}$ before cores
\end{abstract}

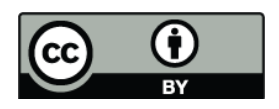

Correspondence to: J. M. Holstein (j.holstein@icbm.de) were taken. A mean sedimentation rate of approximately $2 \mathrm{cmyr}^{-1}$ indicates substantial changes in near coast tidal flat morphology, since sea level rise is at a much lower pace. High sedimentation rates most probably reflect the progradation of flats within the study area. These or similar morphodynamic features also occur in other coastal areas so that inverted redox succession by horizontal or vertical transport may be more common than previously thought. Consequently, regional values for OM remineralization rates may be higher than predicted from surface biogeochemistry.

\section{Introduction}

The chemistry of the interstitial waters of marine environments generally features a predictable zoning resulting from microbial competition of metabolic pathways. Since the terminal electron acceptors ultimately enter the sediment from the overlying ocean, concentrations of dissolved products from redox processes with successively lower free energy yields predominate at successively greater sediment depths. In combination with reduced products from below, vertical cascades of redox processes are sustained (Jørgensen, 2000). Deviations from this sequence, in particular reversed redox successions are usually caused by additional transport mechanisms or rare depositional conditions (D'Hondt et al., 2004).

Shallow coastal seas exhibit both rapid biogeochemical cycling and pronounced morphodynamics. In particular, tidal flats continuously grow or disappear, and they may connect and disconnect laterally. However, little is known about how morphodynamics, lateral pore water flow and biogeochemical cycles are related. How can signals in the vertical

Published by Copernicus Publications on behalf of the European Geosciences Union. 
distribution of major geochemical species like particulate organic matter $(\mathrm{POM})$, ammonium $\left(\mathrm{NH}_{4}\right)$ or sulphate $\left(\mathrm{SO}_{4}\right)$ be indicative of morphological changes? Or, asked from the opposite side, to what extent is the effective remineralization potential of coastal systems shaped by vertical changes (loss and deposition of sediments) and horizontal subsurface transport?

Especially with respect to climate change and the inevitable rise of sea level, the sediment budget needs to be understood in order to assess consequences of shifts in morphodynamic balance (Voss and van Kesteren, 2000). Here, models are important tools to identify key processes, more completely assess collected data, and predict future trends. Inverse modeling allows to constrain parameters that can only be measured with great difficulties (Usbeck et al., 2003; Holstein and Wirtz, 2009)

In this paper, we study the origin of the unusually high reactivity in subsurface sediments at the rim of a tidal flat using a modelling approach. The finding of Wilms et al. (2007) and Beck et al. (2009) that the microbial activity distribution departs from the standard model at two close Wadden Sea back barrier sites allows investigations regarding potential transport mechanisms for organic material (OM) to subsurface sediment, apparently bypassing or uncoupling from the standard age-reactivity correlation of OM (Middelburg, 1989). In particular, we test two hypotheses regarding the most probable transport mechanism of reactive POC to deeper tidal sediments: lateral transport by advection and burial by rapid sedimentation. Our objective was to determine the most plausible transport mechanism for reactive organic matter to subsurface sediments and to constrain biogeochemical parameters for that specific site.

\subsection{The transgressive barrier island depositional system}

The Wadden Sea at the southeastern edge of the North Sea covers one of the worlds largest tidal flat areas. Confined by a meso-tidal barrier island chain with intermittent estuaries of major river systems, the wide siliciclastic back barrier tidal flats host a rather resilient ecosystem in the midst of a densely populated and highly industrialized region (Hertweck, 1994; Ducrotoy and Elliott, 1997; Kock, 1998; Grimm et al., 1999).

As recently as 5000 years BP, the assembly of the modern Wadden Sea with tide-dominated barrier islands was induced due to fading sea level rise and increasing tidal range (Behre et al., 1979). Indeed, coastal protection structures and land reclamation efforts during the last 1000 years eventually stopped the transgression, establishing a new morphodynamic balance (Flemming, 1992). However, in the course of future sea level rise the accretion space will narrow and according to Flemming and Davis Jr. (1994) and Flemming and Bartholomä (1997) the tidal flat depositional system will ultimately disappear.
The coastal morphology is in constant motion. Up to now, the rate of sedimentation easily keeps pace with rising sea-level (recently $1-2 \mathrm{~mm} \mathrm{yr}^{-1}$ ), and the islands and the tidal flats accrete and migrate laterally with time maintaining hydro-morphometric balance (Eisma, 1993; Oost and De Boer, 1994). The gradual morphology reshape is recorded by the sediments if not eroded. While vertical seabed oscillation may add up to more than $500 \mathrm{~mm}$ of sediment deposited or eroded during a year by hydrodynamic forces (mainly tides and storms), they are thought to be mostly event driven, short-term and local, thus having no significant impact on the regional sediment budget (Voss and van Kesteren, 2000; Tilch, 2003). In contrast, long-term average sedimentation rates that deviate from the mean sealevel rise as well as changed flat progradation rates indicate morphodynamic evolution of the tidal flats (Yang et al., 2001, 2006).

\subsection{Water-surface sediment and surface-subsurface exchange}

Decay of organic matter (OM) largely differs between surface and deeper sediments. Bioirrigating and bioturbating organisms considerably affect biogeochemical cycling and transport in the upper $10-20 \mathrm{~cm}$ of the sediment (Aller and Aller, 1998; Berg et al., 2001; D'Andrea et al., 2004; Meysman et al., 2006). Moreover, at the top sediment layer of the sands and muddy sands of the back barrier area, interactions of bottom water currents and sediment topography induce continuous flushing of the uppermost benthic layers (Roy et al., 2002; Precht and Huettel, 2004; Cook and Roy, 2006), leading to rapid exchange of solutes (Precht and Huettel, 2003; Precht et al., 2004) and to filtration of organic particles that are degraded on the spot (Rusch and Huettel, 2000; Huettel et al., 2003). Although the actual contents of reactants may be low, high turnover rates in surface sediments are maintained by the constant supply of reactants and removal of metabolites (Huettel et al., 2006). Pore water advection induced by bottom-flow-topography interaction acts down to $10 \mathrm{~cm}$ deep into the sediment (Huettel et al., 1998). This flow regime, also named "skin-circulation" by Billerbeck et al. (2006), varies on scales of few centimetres and timescales of days in contrast to the "body-circulation", which is a deep-reaching flow regime with small flow velocities driven by tidal pumping (Robinson et al., 2007; Gibbes et al., 2008). Large scale advection is a major contributor to geochemical cycling in meso-tidal coastal sediments (Whiting and Childers, 1989; Robinson et al., 2006) which has been specifically well documented for the Spiekeroog back barrier tidal flats (Billerbeck et al., 2006; Beck et al., 2008; Roy et al., 2008). Subterranean aquifers are sparsely investigated contributors to coastal geochemical cyling, but may have major impact on budgets by connecting large areas and high flow velocities (Schlüter et al., 2004). 


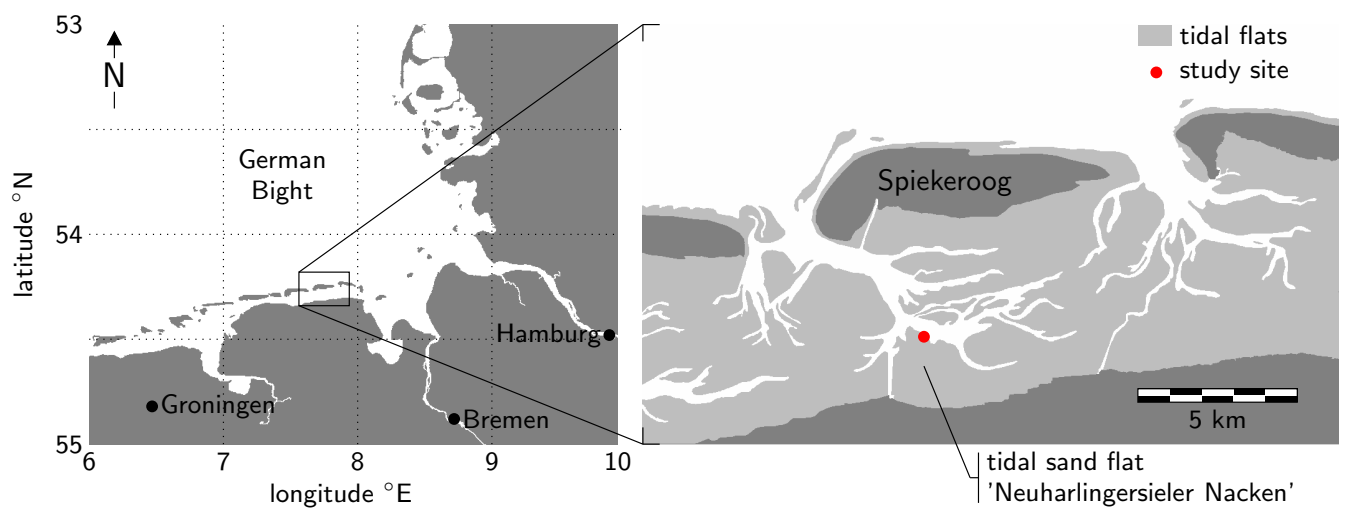

Fig. 1. The study site (red dot) in the back barrier area of Spiekeroog Island, Wadden Sea, Germany is located at the northern rim of an intertidal sand flat (Neuharlingersieler Nacken). The locations of the cores NN1 and NN2 are located along a transect perpendicular to the charted low water line in distances of 10 and $50 \mathrm{~m}$ to the low water line, respectively.

As a general rule, deposits at greater depth usually are much less reactive than surface sediments. As long as the stratigrafic sequence is unaffected by events that may dislocate significant amounts of sediment (e.g. gravity flows or slides) aged autochtonous organic material is remineralized at notedly reduced rates (Middelburg, 1989). Additionally, tighter and less interconnected pore space contributes to the general decrease of turnover rates with depth. Except for continental margin sediments, where gravity flows are a general feature (Hensen et al., 2000; Romero and Hensen, 2002) leaving visible marks in pore water profiles (Hensen et al., 2003), increasing OM reactivity with sediment depth has not been reported to our knowledge.

\section{Study area: sedimentary and geochemical records}

Only at few places the connection between sediment-water interfaces and deeper sediments has been studied. One exception is the back barrier area of Spiekeroog Island (Wadden Sea, southern North Sea) where a location close to the low water line at the northern edge of the Neuharlingersieler Nacken tidal flat (NN1: $\left.53^{\circ} 43.270^{\prime} \mathrm{N}, 7^{\circ} 43.718^{\prime} \mathrm{E}\right)$ has been selected based on previous studies. $5 \mathrm{~m}$ cores were taken three times during the years 2002-2004 (Fig. 1). Another core was recovered $40 \mathrm{~m}$ southward into the direction to the central area of the flat in $2005\left(\mathrm{NN} 2: 53^{\circ} 43.249^{\prime} \mathrm{N}\right.$, $\left.7^{\circ} 43.713^{\prime} \mathrm{E}\right)$. Sedimentological survey of the $5 \mathrm{~m}$ long vibracores by Tilch (2003); Chang et al. (2006b); Wilms et al. (2006b) revealed a trisection of the sediment column shown in Fig. 2: the upper $1.7 \mathrm{~m}$ are composed of sands with intersections of silts (intertidal flat and channel deposits) followed by an approx. $0.7 \mathrm{~m}$ thick shell beds with massive sand interbedding (shell lag deposits). Organic carbon content of the sand and shell layers is $0.3 \%$ on average, but may reach up to $1.2 \%$ in the silty layers. The base consists of greyish muds (saltmarsh and mudflat deposits) containing $1.2 \%$

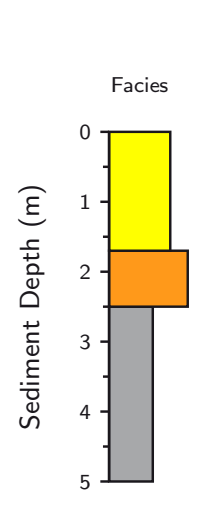

$\mathrm{S}$
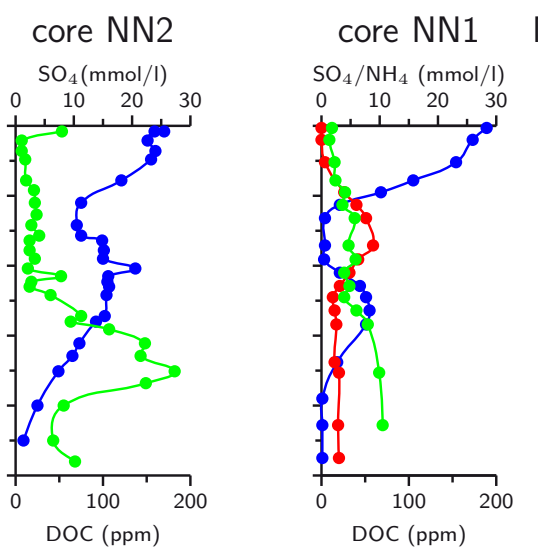

Fig. 2. Lithology and geochemical inventory at the study site. The $\mathrm{N}-\mathrm{S}$ oriented transect covers $40 \mathrm{~m}$ at the nothern rim of the Neuharlingersieler Nacken tidal flat. Facies association according to Chang et al. (2006b): sandy intertidal flat and channel deposits (yellow), shell lag deposits (orange), and saltmarsh/mudflat deposits (gray). Pore water data of DOC (green), $\mathrm{SO}_{4}$ (blue), and $\mathrm{NH}_{4}$ (red) show sulfate depletion between 1 and 2 mbsf accompanied by a $\mathrm{NH}_{4}$ peak (NN1). Core NN1 shows pore water data from 2005 (one of three parallel cores).

POC on average. Sulfate depletion between 1 and 2 mbsf at site $\mathrm{NN} 1$ is accompanied by a clear $\mathrm{NH}_{4}$ peak (Wilms et al., 2007; Beck et al., 2009). The observed variability of sulfate and ammonium signals in the three subsequent cores shows no trend and is indicated by error bars in Fig. 6. These signals cannot be directly related to TOC-rich layers in the sediment. TOC peaks at 1.0 and $1.5 \mathrm{mbsf}$ are both accompanied with increased fine $(<63 \mu \mathrm{m})$ lithoclastic material, which indicates that TOC measurements are less suited to identify active layers since rare labile OM is obscured by abundant refractory OM. High concentrations of acetate at $1.5 \mathrm{mbsf}$, with $2.2 \mathrm{mmol}^{-1}$ making up nearly $50 \%$ of the DOC fraction, 


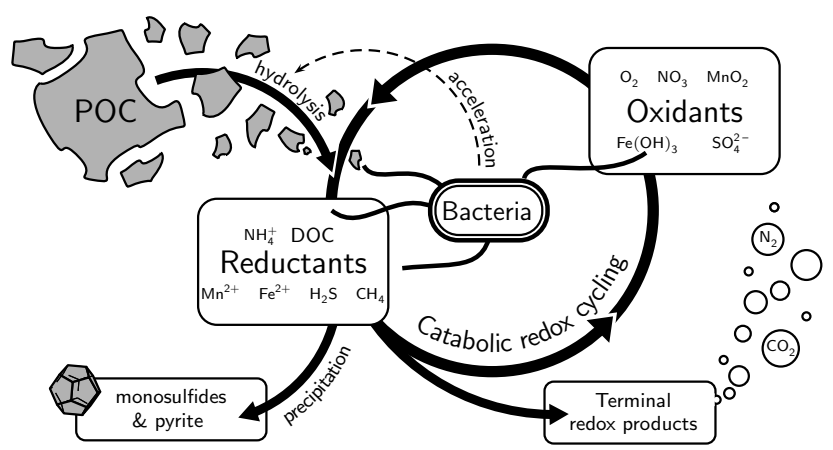

Fig. 3. Sketch of the biochemical cycling scheme in each ISM model box: functional groups of heterotrophic and lithotrophic bacteria conduct the irreversible redox reactions. Educts may participate in subsequent redox reactions. Heterotrophic bacteria accelerate POC hydrolysis.

indicate active fermenting processes. Additionally, the $\Delta^{13} \mathrm{C}$ isotope ratio is elevated here (J. Köster, personal communication, 2008). Microbial investigations by Köpke et al. (2005) and Wilms et al. (2006a) found significantly enhanced activity at the edges of the sulfate free, methanogenic zone. Though less pronounced, ongoing diagenesis is also visible at site NN2 in the sulfate profile. $\mathrm{NH}_{4}$ was not measured.

Sulfate-free methanogenic zones framed by sulfate occurrence above and below are usually interpreted as the standard succession plus a deep intrusion of sulfate which is a natural phenomenon in abyssal deep subsurface sediments and also may serve as a sound interpretation of the sulfate profile at hand recently given by Engelen and Cypionka (2009). However, the massive $\mathrm{NH}_{4}$ peak indicates rapid $\mathrm{OM}$ decay. Consequently, the sulfate free zone is interpreted as a transient feature of recent massive sulfate reduction, deforming an otherwise approximately linear declining sulfate profile.

\section{Reactive-transport modeling}

The Integrated Sediment Model (ISM) (Wirtz, 2003; Holstein and Wirtz, 2009) simulates transport and reactions of chemical species in porous media, particularly resolving carbon degradation. Specific to the ISM compared to many other diagenetic models (e.g., Berner, 1980; Boudreau, 1997) is that most redox reactions are carried out by competing microbial populations (defined according to their catabolic pathways). The decay of OM is calculated for different quality classes, differentiating between enzymatically enhanced hydrolization and quality related consumption of OM by heterotrophic bacteria. A sketch of the biochemical cycling scheme is depicted in Fig. 3. For a comprehensive description of the governing equations, the reader is referred to Holstein and Wirtz (2009). We compared two transport scenarios which both represent partly different implementation and calibration of the ISM.
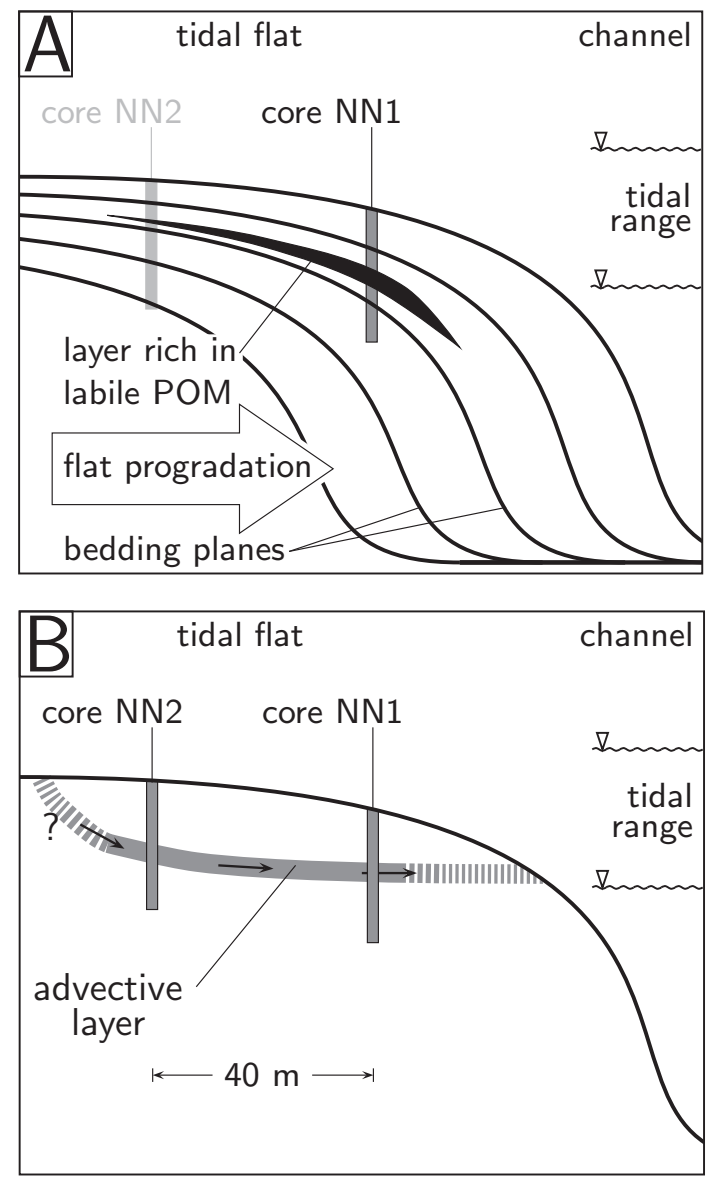

Fig. 4. Alternative scenarios to explain fast OM degradation in deep sediment. (A) Scenario A: eccessive sediment supply causes the tidal flat to vertically grow and laterally prograde into the channel by that burying the labile POM deposit. Scenario calculations are limited to core NN1. "Bedding planes" indicate former surface planes. (B) Scenario B: an advective zone or subterranean aquifer in 1-2 mbsf connects core NN2 and core NN1 to a hypothetical SPOM source upstream of core NN2.

\subsection{Scenarios and model setup}

We here test two plausible scenarios, conceptualized in Fig. 4, of either sedimentation (scenario A) or advection (scenario $\mathrm{B}$ ) being suitable for supplying labile $\mathrm{OM}$ to deeper sediment layers. In scenario A, OM of high or intermediate quality is deposited at the surface and transferred to depth by rapid sedimentation in order to compensate sediment deficits supposably created by ramp propagation into the channel. In scenario $\mathrm{B}$ we assume a subterranean aquifer or advective zone in 1-2 mbsf that connects site NN2 to NN1 and transports intermediate OM from a hypothetical source upstream of NN2 to the study sites. 

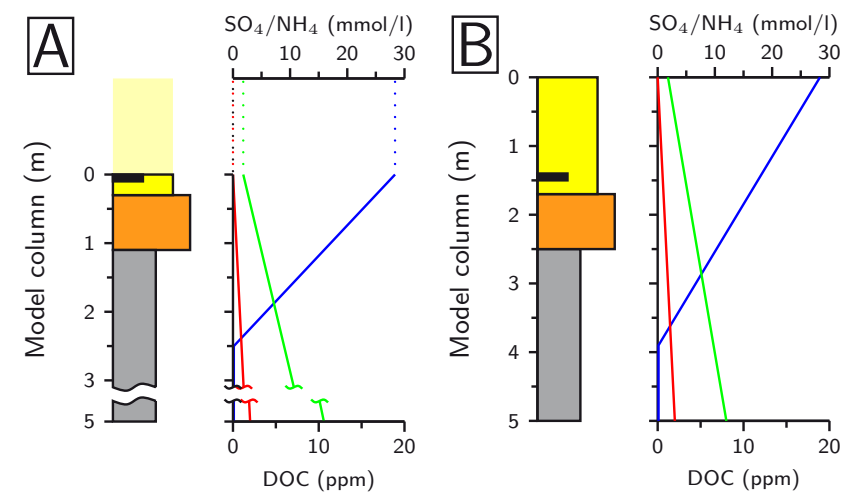

Fig. 5. Model setups of (A) scenario A and (B) scenario B (cf. Fig. 4). Initial pore water profiles of DOC (green), $\mathrm{SO}_{4}$ (blue), and $\mathrm{NH}_{4}($ red $)$. Respective POM and SPOM priming positions are shown in black. Corresponding to facies (cf. Fig. 2), variable sediment diffusivities are assumed: $\phi=0.5, \theta=2.4$ (yellow); $\phi=0.6$, $\theta=4.4$ (orange); $\phi=0.7, \theta=9.4$ (gray).

Both scenarios are represented as specific set-ups of the Integrated Sediment Model (ISM) (Wirtz, 2003; Holstein and Wirtz, 2009) as shown in Fig. 5. For the model calibration in scenario A, we employ a Monte-Carlo parameter variation. From 84 model parameters 9 most critical parameters were chosen based on an extensive sensitivity study carried out by Holstein and Wirtz (2009). We obtain a standard calibration with minimal relative root mean squared error (relative RMSE) of $\mathrm{SO}_{4}$ and $\mathrm{NH}_{4}$ pore water profiles which also serves as base calibration for scenario $\mathrm{B}$.

Both scenarios are implemented as 1-D (one-dimensional) vertical columns consisting of 50 boxes, each $10 \mathrm{~cm}$ thick, representing the sediment column from sediment surface to 5 mbsf. In brief, the boxes consider the following processes and geochemical reactions:

1. Diffusive transport affects all aqueous species within the model area and also leads to import of solutes through the upper boundary during times of water coverage. The upper boundary represents the bottom water overlying the sediment and nutrient concentrations are set to monthly means of measurements of Liebezeit et al. (1996). For oxygen and sulfate, constant concentrations of 0.25 and $24.0 \mathrm{mmol}^{-1}$ respectively are assumed.

2. Bioturbation of solutes and solids is described as a diffusive process. Bioirrigation is implemented as non-local exchange. Both rates decrease exponentially with depth to $5 \%$ of the full value at biomixing depth given in Table 1 . Below, there is no mixing.

3. Redox reactions comprise the primary reactions for $\mathrm{OM}$ degradation according to Froelich et al. (1979), denitrification, and secondary redox reactions. These altogether 20 reactions are mediated by bacteria. Precipita- tion and reoxidation of monosulfide and pyrite formation are controlled thermodynamically only (Holstein and Wirtz, 2009).

4. Hydrolysis of POC controls the accessibility of organic carbon for subsequent redox and metabolic processes

$$
\frac{\partial}{\partial t} \operatorname{poc}_{j}=-\frac{1-\phi}{\phi} r_{j} Q_{10}^{\left(T-T_{0}\right) / 10} \operatorname{poc}_{j}^{2 / 3}(1+h \mathrm{BAC})
$$

where the index $j$ denotes the quality class, $\phi$ the porosity, $h$ quantifies the enzymatic enhancement of hydrolysis, BAC the active bacterial biomass (weighed by the specific growth rate), and poc is the relative POC concentration $\left(\mathrm{POC}(t) / \mathrm{POC}\left(t_{0}\right)\right)$. Regarding hydrolysis, we assume constant particle numbers and acknowledge that hydrolysis is confined to the particle surfaces which scales according to simple geometric considerations with volumetric concentration with exponent $2 / 3$. The model includes the nonlinear $Q_{10}$ temperature term after van't Hoff rule. $T$ and $T_{0}$ denote ambient and standard temperature. Referring to Boudreau (1992), POC is divided into 3 quality classes that differ in their specific rate constant $r_{j}\left(1 \mathrm{~d}^{-1}\right)$ and their Redfield composition according to which $\mathrm{NH}_{4}$ is released into the porewater upon POC destruction. Carbon from hydrolized POC is re-distributed among 3 DOC pools such that the highest quality POC class will also contribute most to the highest quality DOC class. For both scenarios solely POC class 2 is important and the only POC class for which the decay constant was calibrated. POC classes 1 and 3 are precalibrated and are either highly reactive (1) and small quantities are therefore confined to the uppermost layer or refractory (3) and mainly confined to the gray mud layers below $2.5 \mathrm{mbsf}$ (Fig. 2) in concentrations of approximately $1.25 \%$ of bulk dry sediment. POC class 2 collects intermediate material. In scenario A, POC of class 2 is deposited at the top box with $2.5 \%$ dry mass concentration at simulation start, and is incorporated in the sediment body throughout subsequent sedimentation. In scenario B, a $30 \mathrm{~cm}$ thick layer (i.e. 3 boxes) around $1.5 \mathrm{mbsf}$ was primed with $1.0 \%$ intermediate POC. The composition of suspended particulate matter in the overlying bottom water in terms of quality classes is assumed to be 1:5:200 (POC class 1:2:3).

5. Sedimentation (only scenario A) is implemented as a discontinuous process. For example, given the box thickness of $10 \mathrm{~cm}$ and a sedimentation rate of $1 \mathrm{cmyr}^{-1}$, every 10 years all boxes are shifted to the next deeper layer. The content of the lowest model box is lost and the uppermost box is filled with sediment and pore water according to surface conditions. This discontinuous deposition schema avoids numerical diffusion of solid species preventing the loss of OM stratification and sediment characteristics. Compared to continuous 
Table 1. Monte Carlo parameter variation: Parameter ranges, standard calibration (Fig. 6), and relative standard deviation (\%RSD) of parameters from 145 calibrations with average $\% \mathrm{RSD}<5 \%$ with respect to $\mathrm{SO}_{4}$ and $\mathrm{NH}_{4}$ (Fig. 7).

\begin{tabular}{llll}
\hline Parameter & $\begin{array}{l}\text { Variation } \\
\text { range }\end{array}$ & $\begin{array}{l}\text { standard } \\
\text { calibration }\end{array}$ & \%RSD \\
\hline Porosity & $0.4-0.6$ & 0.47 & 8 \\
Sedimentation rate $\left(\mathrm{cmyr}^{-1}\right)$ & $0.1-10$ & 2.2 & 30 \\
Bioturbation coefficient $\left(\mathrm{cm}^{2} \mathrm{day}^{-1}\right)$ & $0-3$ & 0.1 & 31 \\
Bioirrigation coefficient $\left(\mathrm{d}^{-1}\right)$ & $0-50$ & 0.6 & 29 \\
Biomixing depth $(\mathrm{cm})$ & $0-100$ & 45 & 34 \\
Intermediate POC decay constant $\left(\times 10^{-4} \mathrm{~d}^{-1}\right)$ & $0.1-5.0$ & 0.8 & 37 \\
C/N ratio of intermediate POC & $3-15$ & 9.5 & 14 \\
Sulfate reducer yield on DOC & $0.05-0.15$ & 0.08 & 28 \\
Effect of hydrolytic exoenzymes & $1-100$ & 21.5 & 15 \\
\hline
\end{tabular}

sedimentation, we postulate a better reproduction of the sedimentation regime in the Wadden Sea where times of sediment deposition and resuspension vary on a daily, seasonal and annual scale (Chang et al., 2006a).

6. Advection (only scenario B) follows a Lagrangian approach, with an Eulerian 1-D sediment column model embedded in a horizontally moving coordinate system (i.e., the model column is thought to be moving along the advective (horizontal) flow-path). This approach is justified if (i) the reaction rates are slow compared to the flow velocity so that horizontal concentration gradients are negligible compared to vertical gradients which is evident from the $\mathrm{SO}_{4}$ profiles, and (ii) the sediment composition in terms of physicochemical properties is consistent along a horizontal flowpath which is assumed from the sedimentological survey. In addition, a 2-D simulation with coarse spatial resolution (16 unevenly spaced vertical and 32 horizontal boxes) verified the results of the 1-D advective model setup. The intermediate POC decay constant served as the sole master variable. Advective flow velocities are calculated from the distance between NN1 and NN2 and the times needed by the $\mathrm{SO}_{4}$ pore water profile to develop from the initial state via NN2 to a state found at NN1.

\subsection{Parameters of interest}

An extensive parameter variation approach is excellently suited to constrain parameters, provided parameters converge towards a value and the variation range was sensibly chosen. The standard calibration for scenario A was obtained by a total of approximately 34000 simulations that were run with randomly varied parameter values within reasonable limits as given in Table 1. The scenario A standard calibration served as the base calibration for scenario B. In detail, the variation range for porosity was derived from mud content (grain size $<63 \mu \mathrm{m}$ ) (Flemming and Delafontaine, 2000). Since bioturbation is highly variable and uncertain, we used values from
Tromp et al. (1995) for a wide variety of sedimentation rate settings. The decay constant of the POC fraction of interest (intermediate quality) was varied within values just as high as the highly reactive fraction, which is short-lived and therefore exists only in the surface sediment, and just as low as the poorly reactive, refractory fraction. $\mathrm{NH}_{4}$ concentrations, especially peak concentrations at $1.5 \mathrm{mbsf}$ are very sensitive to the $\mathrm{C}: \mathrm{N}$ ratio of the decomposing OM, so OM composition was varied within limits typical for that area (Beck et al., 2008, and references therein). The bacterial yield on $\mathrm{SO}_{4}$ controls the growth of the sulfate reducers. Its value is the Gibbs free energy of the related reaction relative to the yield on $\mathrm{O}_{2}$. Since the understanding of the reactivity of $\mathrm{OM}$ as well as metabolic constraints is fragmentary, bacterial metabolic efficiency may vary and the bacterial yield may significantly differ from the Gibbs free energy of the related reaction (Jørgensen, 1978; Berner, 1980). Introducing OM fractions of different reactivity and the acceleration of the hydrolization by the bacteria themselves is a step towards a more complete description (Rothman and Forney, 2007). Still, our simplified implementation of hydrolization is not verified and therefore a large spectrum of values is considered.

\section{Results and discussion}

In both scenarios, model runs with the calibrated parameter set reproduce $\mathrm{SO}_{4}, \mathrm{NH}_{4}$ and DOC pore water profiles for core NN1 with high accuracy. Model fits stay within single standard deviation as shown in Fig. 6 (for scenario A). In the total of Monte Carlo simulations no indications for several minima were found. The calibrated values given in Table 1, albeit their scatter, should approximate a unique solution.

\subsection{Scenario A - rapid sedimentation}

Given the very good reproduction of the pore water data, and the convergence of well fitting parameter values, the inverse 

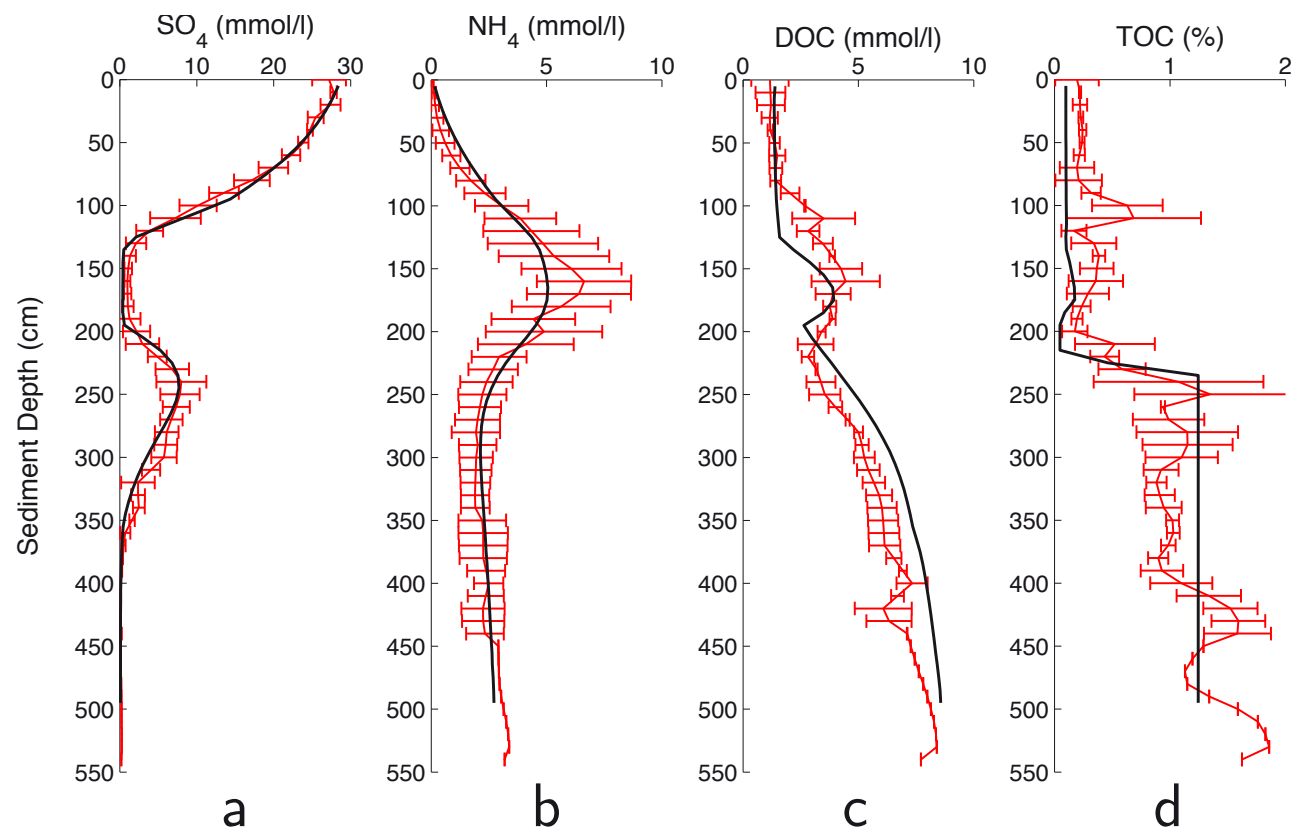

Fig. 6. Scenario A: model results for sulfate, ammonium, DOC and TOC (black line) at a sedimentation rate of $2.2 \mathrm{~cm} \mathrm{yr}^{-1}$ after 64 years compared to average concentrations of three parallel cores (red line). The error bars (red) indicate standard deviation of the parallel cores.

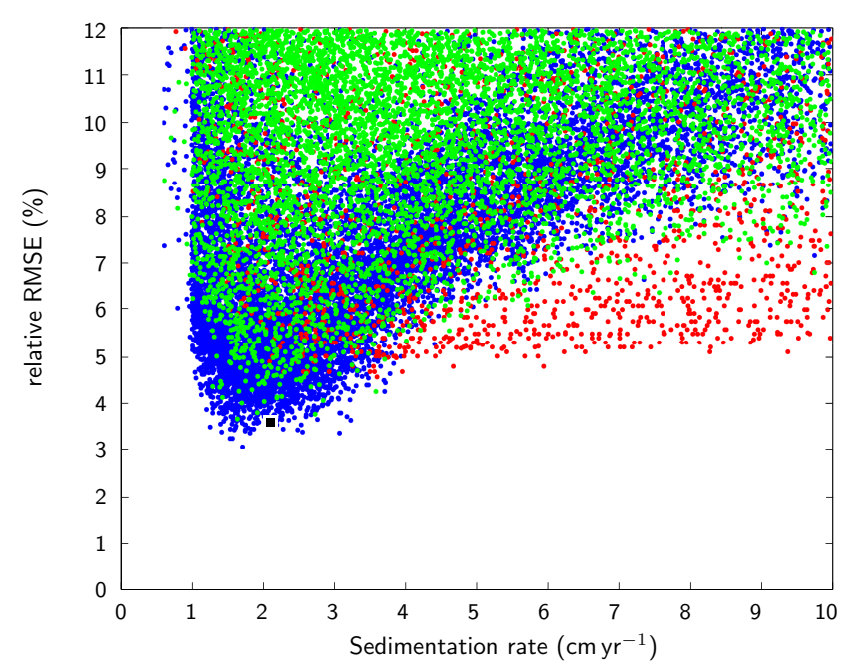

Fig. 7. Model error in a Monte Carlo parameter variation, projected to the effect of variations in the sedimentation rate. The dots shows the relative root mean squared error (relative RMSE) of the pore water profile of $\mathrm{SO}_{4}$ (blue), $\mathrm{NH}_{4}$ (red), and composite of both profiles (green). The black square denotes the best fitting run (standard calibration) given in Table 1 and shown in Fig. 6.

modeling of the sulfate and ammonium profiles yields a robust estimate of recent sedimentation rates. Best model runs in terms of relative RMSE for $\mathrm{SO}_{4}$ and $\mathrm{NH}_{4}$ as shown in Fig. 7 assume sedimentation rates of $1-4 \mathrm{cmyr}^{-1}$. Accordingly, the top $140 \mathrm{~cm}$ of sandy intertidal flat and channel deposits most likely formed during the last 35-140 yrs.
For the simulation with standard calibration as given in Table 1 , the decay of intermediate quality OM at $8 \times 10^{-5} \mathrm{~d}^{-1}$ (corresponding to a halflife of $24 \mathrm{yrs}$ ) provides the DOM used by sulfate reducers. Numerically, this can explain the developing sulfate gap in 1-2 mbsf within 64 years. Weaker constraints regarding the sedimentation rate follow from the ammonium profile fitting, but at rates below $1 \mathrm{cmyr}^{-1}$ the model error drastically increases. Hence, the sandy flat and channel deposits, which make up the upper section of the cores, must have been deposited at rates significantly higher than required just to keep up with sea level rise. The relative RMSEs of DOC and TOC (not shown) are largely insensitive to the sedimentation rate.

The best 145 model calibrations (composite $\mathrm{SO}_{4}$ and $\mathrm{NH}_{4}$ relative $\mathrm{RMSE}<5 \%$ ) represent the uncertainty of the calibrated values as well as the partial overlap of parameter functions. In general, parameters are less constrained than in a comparable study by Beck et al. (2009) which was expected because we vary more parameters here. The POC decay constant, the yield on $\mathrm{SO}_{4}$ and the specific enhancement of hydrolytic exoenzymes all affect the speed in which sulfate reducers degrade the organic matter. Due to a similarly accelerating effect these highly important parameters for OM degradation (Holstein and Wirtz, 2009) were only moderately constrained and best calibrations have relative standard deviations of $15-37 \%$. In contrast, porosity changes produce a rather unequivocal response, demonstrating the prominent role of sediment transport characteristics for the model results. Best fitting porosity of the deposited sediment was estimated to be 0.46 which is in good agreement with a range 
of $0.37-0.43$ calculated from mud content by Flemming and Delafontaine (2000) for East Frisian Wadden Sea intertidal surface sediments.

The calibrated bioturbation coefficient accurately fits estimates for coastal systems with reported sedimentation rates of few $\mathrm{cmyr}^{-1}$ (Tromp et al., 1995, and references therein). Additionally, a bioturbation/-irrigation depth of $54 \mathrm{~cm}$ is found to be most compatible with the observed convex or kink shape of the sulfate profile. However, this estimate clearly exceeds the usually reported values of $10-30 \mathrm{~cm}$ for bioturbation and of $10-20 \mathrm{~cm}$ for bioirrigation (Boudreau, 1994, 1998; Furukawa et al., 2000; Sandnes et al., 2000; Meile et al., 2001; Crusius et al., 2004). The latter is the accepted burrow depth of the lugworm Arenicola marina and Heteromastus filiformis, both most abundant macrofauna species of the study area. Bioturbation may reach as deep as $0.5 \mathrm{mbsf}$ in sediments overlying high-productivity areas (Wetzel, 1981) and some species (e.g., Callianassa subterranean and Maxmuelleria lankesteri), though undocumented in the investigated habitat, are known to have burrows reaching such depth (Koretsky et al., 2002). Another explanation for kink shape pore water profiles is that sedimentation of the upper $0.5 \mathrm{~m}$ happened faster than relaxation of the concentration gradient (Hensen et al., 2003). This scenario would require deposition during one or few events, which is in line with the sedimentation pattern proposed by Chang et al. (2006b) which also explains the loss of bioturbation structures being a result of concordant resuspension and deposition events.

By setting the Redfield ratio of $\mathrm{C}: \mathrm{N}$ to 9.5 , the height of the ammonium peak of around $6 \mathrm{mmoll}^{-1}$ and the bell shape of the ammonium pore water profile can be reproduced. This calibrated value exceeds the standard Redfield $\mathrm{C}: \mathrm{N}$ ratio of 6.6. But it is in the stoichiometric range of suspended particular organic matter (SPOM) in the open water column of the study area (around 7.8; Lunau et al., 2006) and comparable to an integrated value of 8.6 for the upper $3 \mathrm{~m}$ of sediment on a neighboring flat by Beck et al. (2008).

Since bacterial yields are relative energy yields, the sulfate reducers yield on DOC of 0.08 means that they gain $8 \%$ of the energy that oxic heterotrophs would gain from one unit of DOC (dissimilatory metabolism) which can then converted into growth (assimilatory metabolism). If just the Gibbs free energies of the corresponding reactions after Froelich et al. (1979) are considered, the energy yield of sulfate reducers should be around 0.12 . Given the relatively high relative standard deviation of $28 \%$, the calibrated value seems reasonable since reported bacterial growth efficiencies also show a wide scatter (Payne and Wiebe, 1978; Russell and Cook, 1995).

\subsection{Scenario B - advection}

Reasonable model-data fits were also found for scenario B. This is not surprising since both scenarios differ only in

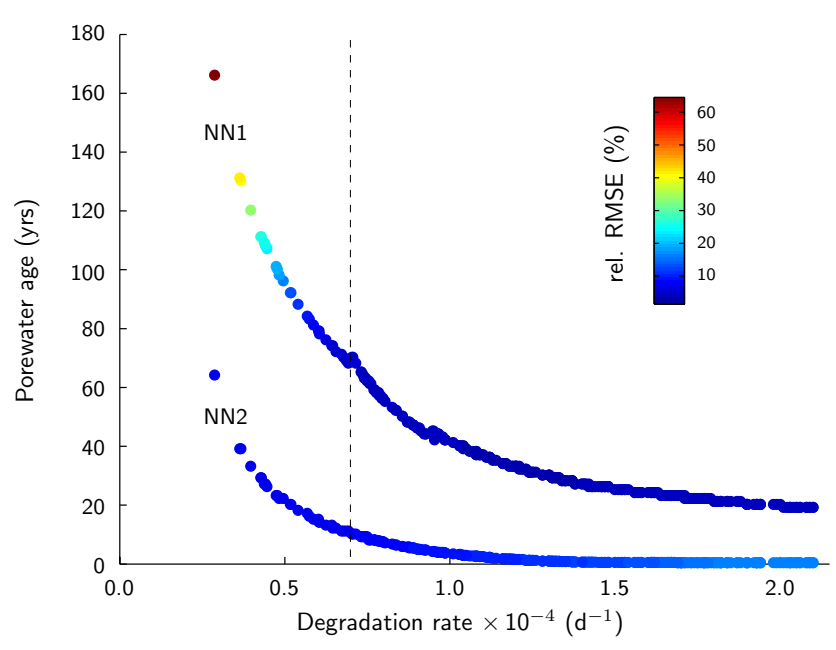

Fig. 8. Scenario B pore water age at core NN2 and NN1 in relation to the intermediate POC decay constant according to pore water sulfate evolution. Relative root mean square errors (relative RMSE) of a particular best fit are indicated by color. Minimal relative RMSE is attained at $0.7 \times 10^{-4} \mathrm{~d}^{-1}$ (dashed line).

the mechanism which is used to transfer OM to depth. In both scenarios $\mathrm{OM}$ is subject to the same array of processes, with comparable results regarding degradation and pore water evolution. For core NN2, which is not used for the model calibration of scenario A, the sulfate fit is less satisfying due to the fact that the whole profile, including the sulfate minimum and the sulfate bulge below, is slightly elevated with respect to the core NN1 profile. Model error for sulfate and ammonium of core NN2 and NN1 become minimal at a degradation rate of $0.7 \times 10^{-4} \mathrm{~d}^{-1}$ (Fig. 8). According to timing and geometry, this corresponds to a macroscopic flow velocity of $1.4 \mathrm{myr}^{-1}$ (Fig. 9a). Assuming invariant aquifer dimensions and conditions, the OM source is then located $6 \mathrm{~m}$ upstream of core NN2 (Fig. 9b). That way, it takes approximately 10 years for the sulfate profile to develop the shape observed at core NN2 and another 60 years to develop the shape observed at core NN1 as confirmed by a 2-D model depicted in Fig. 10 showing the applicability of the the Lagrangian. Due to coarse vertical and horizontal resolution, RMSE calculations (of pore water profiles) were done with the 1-D model results to obtain optimal OM degradation rates and pore water age. Additionally, the relatively high vertical resolution near the seafloor (compared to the $10 \mathrm{~cm}$ resolution of the 1-D models) lead to no significant improvement of the effect of bioturbation and bioirrigation on inspected pore water solutes. The OM degradation rate, as a parameter, most effectively controls the pace at which the sulfate profile evolves and is found to be around $0.5-1.0 \times 10^{-4} \mathrm{~d}^{-1}$. At lower rates, sulfate reduction is too weak to produce a sulfate-free zone at all, which is reflected by increasing relative RMSE for core NN1 sulfate fits as depicted in Fig. 8. Higher rates presupposes the OM source to be situated so 


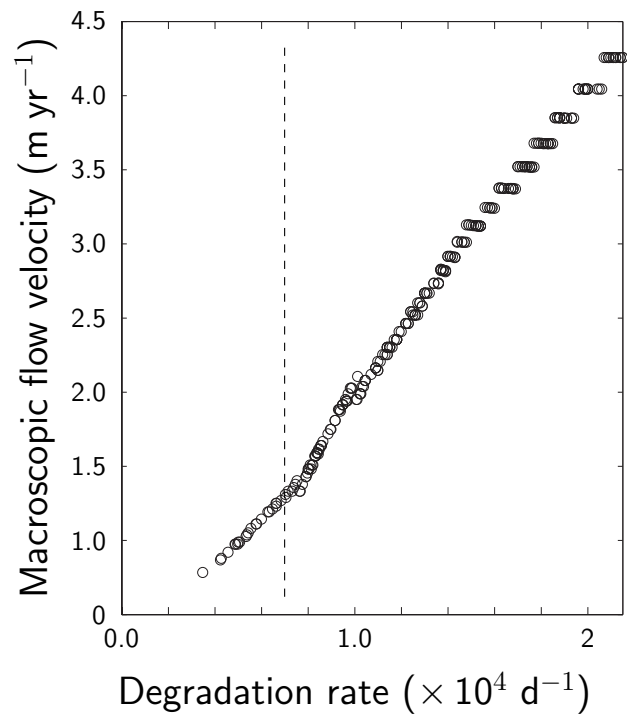

a

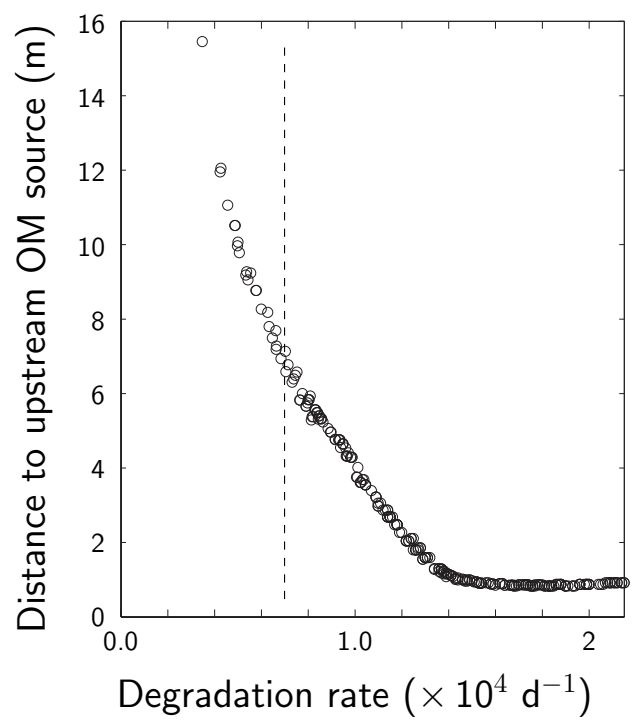

b

Fig. 9. Flow parameters of scenario B and their relation to the intermediate POC decay constant. (a) Macroscopic flow velocity required to cover the distance of $40 \mathrm{~m}$ between core NN2 and NN1 in the length of time between the best fits of sulfate pore water profiles at respective locations. (b) Distance of core NN2 to the hypothetical source of OM. The dashed line marks the minimal relative RMSE at $0.7 \times 10^{-4} \mathrm{~d}^{-1}$.
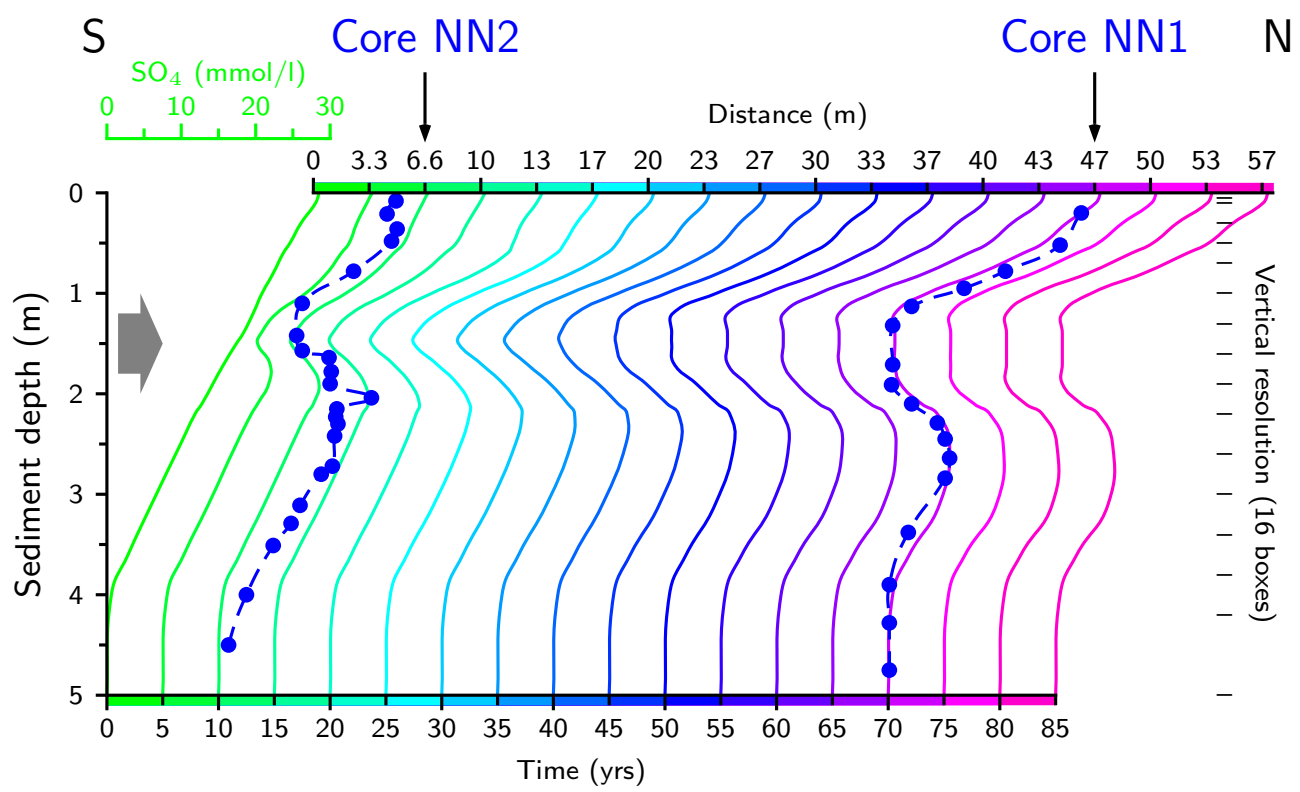

Fig. 10. Model pore water $\mathrm{SO}_{4}$ evolution (varicolored) along the flow path with a degradation rate of intermediate $\mathrm{POC}$ of $0.7 \times 10^{-4} \mathrm{~d}^{-1}$ yielding best fits (minimal RMSE) for field data $\mathrm{SO}_{4}$ pore water profile (blue). Pore water reaches NN2 after 10 years, approximately $7 \mathrm{~m}$ from POC source, and for NN1 after another 60 years, 40 m downstream of NN2.

close to NN2 that consistently a subsurface location has to be assumed. In this case advection must be discarded as the process to relocate OM from surface to depth.

In addition, DOC pore water profiles of cores NN1 and NN2 document that the dissolved compound alone cannot be responsible for the observed sulfate reduction. The measured
DOC concentration is too low and exhibits no change from core NN2 to NN1. Therefore, the supplied carbon has to arrive as suspended particles (that exceed $1.2 \mu \mathrm{m}$, which was the filter size for pore water extraction by Beck et al., 2009). Retention of SPOM has not been considered in the model calculations. It would slow down carbon transport, delaying 
pore water evolution and, as a result, further decrease the distance from core NN1 to the hypothetical carbon source.

Though the existence of an aquifer cannot be excluded from the investigations, the heavily curved flowpaths required for this scenario point to tidal pumping as the driving force for underground water flow. Notedly, macroscopic flow velocities projected by Wilson and Gardner (2006); Roy et al. (2008) are compatible with our model derived estimates.

\subsection{General discussion}

Taken together, in scenario A, the sulfate profile is reproduced best, while the peak in the ammonium profile could not be reproduced to the same extent. The initialized OM pulse is presumably too broad to generate such a distinct peak. In the model, the DOC peak between 1.5 and 2.0 mbsf consists of intermediate DOC, which is situated above a layer of refractory compounds. This peak is less pronounced than empirical data suggest but more pronounced than the distinct acetate peak at this site (not shown). As a result, some of the DOC may be refractory. The observed total organic carbon (TOC) profile is satisfactorily reproduced. An exception is the simulated TOC peak above $2.0 \mathrm{mbsf}$ (consisting of intermediate quality TOC). The field data display a more complex picture with higher values at 1.0 and $1.5 \mathrm{mbsf}$.

From the available model-related field data we used for model calibration, $\mathrm{CH}_{4}$ was excluded since it reacts extremely sensitive to the POC decay constant, so both could not simultaneously be calibrated. However, on the relatively short timescale examined, methane does not effectively move up and down the sulfate front since measured methane gradients are of the order of only $0.1 \mathrm{mmol}^{-1} \mathrm{~m}^{-1}$ ). For the calibration found, the methanogenesis rate can in principle be calibrated to fit the methane profile (Holstein and Wirtz, 2009).

The advection hypothesis yet appears implausible, since the geometric premises required for scenario B are highly specific, even contrived; a reasonable probability cannot be sustained for them at this site. Since tidal pumping affects the whole sediment body, advection would not be restricted to a certain layer unless obstructed by sediment properties for which there is no lithologic evidence. In case of unhindered flow, the carbon source needs to be very confined, ruling out water column SPOM as carbon source. For example, a macroalgae agglomerate buried in the surface sediment few meters upstream of core NN2 might create a confined SPOM plume to match observations. Given the constant reworking of the surface sediment by hydrodynamic forces, the carbon source is not likely to stay put for at least $60 \mathrm{yrs}$ to cause effect at both sites NN2 and NN1.

Sedimentation rates of a few $\mathrm{cmyr}^{-1}$ over decades signal morphologic change. The assumed tidal flat progradation, as a manifestation of morphodynamics, agrees with nautical charts of the years 1866-2003 for our study area (Tilch, 2003). While most of the northern and northeastern parts of the tidal flats that form the southern and southwestern bank of the main tidal channel (Neuharlingersieler Nacken and Janssand) suffer from erosion following the general trend towards higher energies, the study area receives sediment. For $2 \mathrm{~m}$ of young sediment to deposit, it would require a flat progradation of a little less than $1 \mathrm{~m} \mathrm{yr}^{-1}$ into the channel at an inclination of $2.3^{\circ}$ of tidal flat surface plane during 60 years. Since great channels may laterally relocate 25 to $30 \mathrm{~m} \mathrm{yr}^{-1}$ on average according to Lüders (1934) it seems a conceivable hypothesis.

High rates of sediment accumulation and thus accretion have been observed in various tidally influenced systems like mangrove forests, estuarines, or barrier islands (Alongi et al., 2005; Lopez-Cadavid, 2007). Reported vertical deposition rates range within the order of one to several $\mathrm{cm} \mathrm{yr}^{-1}$, reaching values of $20 \mathrm{~cm} \mathrm{yr}^{-1}$ or more (Wilber et al., 1990; Yang et al., 2001). Occasional massive deposition of organic material (e.g., from micro- or macroalgal blooms) also have been documented in many coastal systems (Cadée, 1996; Neira and Rackemann, 1996; Castel et al., 1996; Raffaelli et al., 1998), often in the context of eutrophication (Livingston, 2001)). In conjunction with high sediment accumulation rates, such events eventually have created similar subsurface zones of high remineralization activity. If the less likely but still conceivable second scenario of aquifer flow holds true, our results would similarly apply to other sites and many other coastal systems (Cooper Jr., 1959; Valiela et al., 1978; Johannes, 1980; Riedel et al., 2010). Akamatsua et al. (2009) give an example of how subsurface advection beneath a mangrove forest generates a maximum in organic carbon at depth of $1 \mathrm{~m}$.

\section{Conclusions}

We compared the two most probable processes for the rapid transfer of reactive OM into deeper sediment layers. Both sedimentation and advection could in general explain the observed profiles of $\mathrm{SO}_{4}, \mathrm{NH}_{4}$, DOC and TOC. Given the assumptions for carbon source location and flow geometry, the advection hypothesis appears rather improbable. Provided higher flow velocities, however, pore water advection principally may relocate reactive organic matter over much longer distances and deep into the sediment.

The sedimentation hypothesis implies the rapid compensation of a great sediment deficit, which might have lead to tidal flat progradation. Inversely modeled sedimentation rates and values for progradation rates are in the range of observations. The estimates for the Redfield ratio and the decay rate of the OM organic matter that was initially deposited in the surface sediment suggests a POM composition typical for the area (i.e. moderately nitrogen depleted and of intermediate reactivity). 
Taken together, we suggest scenario A to be more probable. In morphodynamically very active areas like many coastal systems, this would have consequences for the biogeochemical fingerprint of the entire sediment body. If layers of high OM content become occasionally buried within few decades, estimates of carbon budget parameters (e.g., organic matter preservation efficiency, methane production, or nutrient remineralization) will depart from extrapolations from surface layer or distant deeper sediments. In particular methane emissions from coastal areas will thus be higher than projected estimates that do not take into account larger amounts of buried but still relatively fresh OM in greater depth.

We demonstrated that models can be indispensable for a sound interpretation of biogeochemical data. By using automated model calibration, we were in particular able to infer the average sedimentation rate during the last decades. On this timescale, sedimentation rates are rarely estimated for marine environments. Morphodynamic changes like flat progradation are not restricted to the study site. We therefore suggest that at many shallow coasts $\mathrm{OM}$ turnover (connected with significant production of $\mathrm{CO}_{2}, \mathrm{~N}_{2} \mathrm{O}$ or $\mathrm{CH}_{4}$ ) will be more intense than apparent from surface-restricted studies.

Acknowledgements. The authors greatly appreciate the constructive comments of Beate Köpke, Reinhard Wilms and Bert Engelen. Special thanks go to Jürgen Köster for acetate and $\Delta^{13} \mathrm{C}$ data. This work was supported by the DFG project FOR 432.

Edited by: C. P. Slomp

\section{References}

Akamatsua, Y., Ikeda, S., and Toda, Y.: Transport of nutrients and organic matter in a mangrove swamp, Estuarine, Coastal and Shelf Science, 82, 233-242, 2009.

Aller, R. C. and Aller, J. Y.: The effect of biogenic irrigation intensity and solute exchange on diagenetic reaction rates in marine sediments, J. Mar. Res., 56, 905-936, 1998.

Alongi, D., Pfitzner, J., Trott, L., Tirendi, F., Dixon, P., and Klumpp, D.: Rapid sediment accumulation and microbial mineralization in forests of the mangrove Kandelia candel in the Jiulongjiang Estuary, China, Estuarine, Coastal and Shelf Science, 63, 605618, 2005.

Beck, M., Dellwig, O., Holstein, J. M., Grunwald, M., Liebezeit, G., Schnetger, B., and Brumsack, H.-J.: Sulphate, dissolved organic carbon, nutrients and terminal metabolic products in deep pore waters of an intertidal flat, Biogeochemistry, 89, 221-238, doi:10.1007/s10533-008-9215-6, 2008.

Beck, M., Köster, J., Engelen, B., Holstein, J. M., Gittel, A., Könneke, M., Riedel, T., Wirtz, K. W., Cypionka, H., Rullkötter, J., and Brumsack, H.-J.: Deep pore water profiles reflect enhanced microbial activity towards tidal flat margins, Ocean Dynam., 59, 371-383, doi:10.1007/s10236-008-0176-z, 2009.

Behre, K.-E., Menke, B., and Streif, H.: The Quarternary geological developement of the german part of the North Sea, in:
The Quarternary History of the North Sea, edited by: Oele, R., Schüttenheim, R. T. E., and Wiggers, A. J., 85-113, 1979.

Berg, P., Rysgaard, S., Funch, P., and Sejr, M. K.: Effect of bioturbation on solutes and solids in marine sediments, Aquat. Microb. Ecol., 26, 81-94, 2001.

Berner, R. A.: Early diagenesis - a theoretical approach, Princton University Press, Princton, NJ, 1980.

Billerbeck, M., Werner, U., Polerecky, L., Walpersdorf, E., deBeer, D., and Huettel, M.: Surficial and deep pore water circulation governs spatial and temporal scales of nutrient recycling in intertidal sand flat sediment, Mar. Ecol.-Prog. Ser., 326, 61-76, 2006.

Boudreau, B. P.: A kinetic model for microbic organic-matter decomposition in marine sediments, Aquat. Microb. Ecol., 102, 114, 1992.

Boudreau, B. P.: Is burial velocity a master parameter for bioturbation, Geochim. Cosmochim. Ac., 58, 1243-1249, 1994.

Boudreau, B. P.: Diagenetic models and their implementation, Modelling transport and reactions in aquatic sediments, Springer, Berlin, 1997.

Boudreau, B. P.: Mean mixed depth of sediments: the wherefore and the why, Limnol. Oceanogr., 43, 524-526, 1998.

Cadée, G.: Accumulation and sedimentation of Phaeocystis globosa in the Dutch Wadden Sea, J. Sea Res., 36, 321-327, 1996.

Castel, J., Caumette, P., and Herbert, R.: Eutrophication gradients in coastal lagoons as exemplified by the Bassin d'Arcachon and the Étang du Prévost, Hydrobiologia, 329, 9-28, 1996.

Chang, T. S., Bartholoma, A., and Flemming, B. W.: Seasonal dynamics of fine-grained sediments in a back-barrier tidal basin of the German Wadden Sea (Southern North Sea), J. Coastal Res., 22, 328-338, 2006a.

Chang, T. S., Flemming, B. W., Tilch, E., Bartholoma, A., and Wostmann, R.: Late Holocene stratigraphic evolution of a backbarrier tidal basin in the East Frisian Wadden Sea, southern North Sea: transgressive deposition and its preservation potential, Facies, 52, 329-340, 2006b.

Cook, P. L. M. and Roy, H.: Advective relief of $\mathrm{CO}_{2}$ limitation in microphytobenthos in highly productive sandy sediments, Limnol. Oceanogr., 51, 1594-1601, 2006.

Cooper Jr., H.: A Hypothesis Concerning the Dynamic Balance of Fresh Water and Salt Water in a Coastal Aquifer, J. Geophys. Res., 64, 461-467, 1959.

Crusius, J., Bothner, M. H., and Sommerfield, C. K.: Bioturbation depths, rates and processes in Massachusetts Bay sediments inferred from modeling of $\mathrm{Pb}-210$ and $\mathrm{Pu} 239+240$ profiles, Estuar. Coast. Shelf S., 61, 643-655, 2004.

D'Andrea, A. F., Lopez, G. R., and Aller, R. C.: Rapid physical and biological particle mixing on an intertidal sandflat, J. Mar. Res. 62, 67-92, 2004.

D'Hondt, S., Jorgensen, B. B., Miller, D. J., Batzke, A., Blake, R., Cragg, B. A., Cypionka, H., Dickens, G. R., Ferdelman, T., Hinrichs, K. U., Holm, N. G., Mitterer, R., Spivack, A., Wang, G. Z., Bekins, B., Engelen, B., Ford, K., Gettemy, G., Rutherford, S. D., Sass, H., Skilbeck, C. G., Aiello, I. W., Guerin, G., House, C. H., Inagaki, F., Meister, P., Naehr, T., Niitsuma, S., Parkes, R. J., Schippers, A., Smith, D. C., Teske, A., Wiegel, J., Padilla, C. N., and Acosta, J. L. S.: Distributions of microbial activities in deep subseafloor sediments, Science, 306, 2216-2221, 2004.

Ducrotoy, J.-P. and Elliott, M.: Interrelations between science and policy-making: the North Sea example, Mar. Pollut. Bull., 34, 
686-701, 1997.

Eisma, D.: Suspended matter in the aquatic environment, Springer, Berlin, 1993.

Engelen, B. and Cypionka, H.: The subsurface of tidal-flat sediments as a model for the deep biosphere, Ocean Dynam., 59, 385-391, 2009.

Flemming, B. and Bartholomä, A.: Response of the Wadden Sea to a rising sea-level: a predictive empirical model, German Journal of Hydrography, 49, 343-353, 1997.

Flemming, B. W.: Zur holozänen Entwicklung, Morphologie und faziellen Gliederung der ostfriesischen Insel Spiekeroog (südliche Nordsee), Berichte Senkenberg Am Meer, 91/3, 51 pp., 1992.

Flemming, B. W. and Davis Jr., R. A.: Holocene evolution, morphodynamics and sedimentology of the Spiekeroog barrier island system (southern North Sea), Senck. Marit., 24, 117-155, 1994.

Flemming, B. W. and Delafontaine, M. T.: Mass physical properties of muddy intertidal sediments: some applications, misapplications and non-applications, Cont. Shelf Res., 20, 1179-1197, 2000.

Froelich, P. N., Klinkhammer, G. P., Bender, M. L., Luedtke, N. A., Heath, G. R., Cullen, D., Dauphin, P., Hammond, D., Hartman, B., and Maynard, V.: Early oxidation of organic matter in pelagic sediments of the eastern equatorial Atlantic-suboxic diagenesis, Geochim. Cosmochim. Ac., 43, 1075-1090, 1979.

Furukawa, Y., Bentley, S. J., Shiller, A. M., Lavoie, D. L., and Cappellen, P. V.: The role of biologically-enhanced pore water transport in early diagenesis: an example from carbonate sediments in the vicinity of North Key Harbor, Dry Tortugas National Park, Florida, J. Mar. Res., 58, 493-522, 2000.

Gibbes, B., Robinson, C., Carey, H., Li, L., and Lockington, D.: Tidally driven pore water exchange in offshore intertidal sandbanks: Part I. Field measurements, Estuar. Coast. Shelf S., 79, 121-132, 2008.

Grimm, V., Bietz, H., Günther, C. P., Hild, A., Villbrandt, M., and Niesel, V.: Stability properties in the Wadden Sea, in: The Wadden Sea Ecosystem-stability properties and mechanisms, edited by: Dittmann, S., 227-259, Springer, Berlin, 1999.

Hensen, C., Zabel, M., and Schulz, H. D.: A comparison of benthic nutrient fluxes from deep-sea sediments off Namibia and Argentina, Deep-Sea Res. Pt. II, 47, 2029-2050, 2000.

Hensen, C., Zabel, M., Pfeifer, K., Schwenk, T., Kasten, S., Riedinger, N., Schulz, H. D., and Boetius, A.: Control of sulfate pore-water profiles by sedimentary events and the significance of anaerobic oxidation of methane for the burial of sulfur in marine sediments, Geochim. Cosmochim. Ac., 67, 2631-2647, 2003.

Hertweck, G.: Zonation of benthos and lebensspuren in the tidal flats of the Jade Bay, southern North Sea, Senck. Marit., 24, 157$170,1994$.

Holstein, J. M. and Wirtz, K. W.: Sensitivity analysis of nitrogen and carbon cycling in marine sediments, Estuar. Coast. Shelf S., 82, 632-644, doi:10.1016/j.ecss.2009.02.008, 2009.

Huettel, M., Ziebis, W., Forster, S., and Luther, G. W.: Advective transport affecting metal and nutrient distributions and interfacial fluxes in permeable sediments, Geochim. Cosmochim. Ac., 62, 613-631, 1998.

Huettel, M., Roy, H., Precht, E., and Ehrenhauss, S.: Hydrodynamical impact on biogeochemical processes in aquatic sediments, Hydrobiologia, 494, 231-236, 2003.
Huettel, M., Wesnigk, J., Cook, P., Wenzhöfer, F., Massel, S., Weslawski, J. M., Middelburg, J. J., Beusekom, J. E. E. v., Glud, R., Jaszewski, J., and Eskildsen, K.: Coastal Sands as biocatalytical filters. A succesful project on filtration and nutrient cycling in sandy coastal sediments, Coastline, 15, 19-21, 2006.

Johannes, R. E.: The ecological significance of the submarine discharge of groundwater, Mar. Ecol.-Prog. Ser., 3, 365-373, 1980.

Jørgensen, B. B.: Comparison of methods for the quantification of bacterial sulfate reduction in coastal marine-sediments. 2. Calculation from mathematical-models, Geomicrobiol. J., 1, 29-47, 1978.

Jørgensen, B. B.: Bacteria and marine Biogeochemistry, in: Marine Geochemistry, 173-207, Springer, Berlin, 2000.

Kock, K.: Das Watt: Lebensraum auf den zweiten Blick, Boyens \& Co., Heide, 1998.

Köpke, B., Wilms, R., Engelen, B., Cypionka, H., and Sass, H.: Microbial diversity in coastal subsurface sediments: a cultivation approach using various electron acceptors and substrate gradients, Appl. Environ. Microb., 71, 7819-7830, 2005.

Koretsky, C., Meile, C., and Van Cappellen, P.: Quantifying bioirrigation using ecological parameters: a stochastic approach, Geochem. T., 3, 17-30, 2002.

Liebezeit, G., Behrends, B., and Kraul, T.: Variability of nutrients and particulate matter in backbarrier tidal flats of the East Frisian Wadden Sea, Senckenbergiana, 26, 195-202, 1996.

Livingston, R.: Eutrophication processes in coastal systems: Origin and succession of plankton blooms and effects on secondary production in Gulf Coast estuaries, CRC Press, 2001.

Lopez-Cadavid, G.: The late Quaternary evolution of the Apalachicola Barrier Island Complex, North-East Gulf of Mexico, as determined from optical dating, ETD Collection for McMaster University, 2007.

Lüders, K.: Das Wandern der Prile, Abhandlungen des Naturwissenschaftlichen Vereins zu Bremen, 29, 19-32, 1934.

Lunau, M., Lemke, A., Dellwig, O., and Simon, M.: Physical and biogeochemical controls of microaggregate dynamics in a tidally affected coastal ecosystem, Limnol. Oceanogr., 51, 847-859, 2006.

Meile, C., Koretsky, C., and Van Cappellen, P.: Quantifying bioirrigation in aquatic sediments: an inverse modeling approach, Limnol. Oceanogr., 46, 164-177, 2001.

Meysman, F. J., Middelburg, J. J., and Heip, C. H.: Bioturbation: a fresh look at Darwin's last idea, Trends Ecol. Evol., 21, 688-695, doi:10.1016/j.tree.2006.08.002, 2006.

Middelburg, J. J.: A simple rate model for organic-matter decomposition in marine-sediments, Geochim. Cosmochim. Ac., 53, 1577-1581, 1989.

Neira, C. and Rackemann, M.: Black spots produced by buried macroalgae in intertidal sandy sediments of the Wadden Sea: effects on the meiobenthos, J. Sea Res., 36, 153-170, 1996.

Oost, A. and De Boer, P. L.: Sedimentology and developement of barrier islands, edd-tidal deltas, inlets and backbarrier areas of the dutch Wadden Sea, Senck. Marit., 24, 65-115, 1994.

Payne, W. J. and Wiebe, W. J.: Growth yield and efficiency in chemosynthetic microorganisms, Ann. Rev. Microbiol., 32, 15583, 1978.

Precht, E. and Huettel, M.: Advective pore-water exchange driven by surface gravity waves and its ecological implications, Limnol. Oceanogr., 48, 1674-1684, 2003. 
Precht, E. and Huettel, M.: Rapid wave-driven advective pore water exchange in a permeable coastal sediment, J. Sea Res., 51, 93107, 2004.

Precht, E., Franke, U., Polerecky, L., and Huettel, M.: Oxygen dynamics in permeable sediments with wave-driven pore water exchange, Limnol. Oceanogr., 49, 693-705, 2004.

Raffaelli, D. G., Raven, J. A., and Poole, L. J.: Ecological impact of green macroalgal blooms, in: Oceanography And Marine Biology: An Annual Review, ULC Press, 36, 97-125, 1998.

Riedel, T., Lettmann, K., Beck, M., and Brumsack, H.-J.: Tidal variations in groundwater storage and associated discharge from an intertidal coastal aquifer, J. Geophys. Res.-Oceans, 115, C04013, doi:10.1029/2009JC005544, 2010.

Robinson, C., Gibbes, B., and Li, L.: Driving mechanisms for groundwater flow and salt transport in a subterranean estuary, Geophys. Res. Lett., 33, L03402, doi:10.1029/2005GL025247, 2006.

Robinson, C., Li, L., and Prommer, H.: Tide-induced recirculation across the aquifer-ocean interface, Water Resour. Res., 43, W07428, doi:10.1029/2006WR005679, 2007.

Romero, O. and Hensen, C.: Oceanographic control of biogenic opal and diatoms in surface sediments of the Southwestern Atlantic, Mar. Geol., 186, 263-280, 2002.

Rothman, D. H. and Forney, D. C.: Physical model for the decay and preservation of marine organic carbon, Science, 316, 13251328, 2007.

Roy, H., Huttel, M., and Jørgensen, B. B.: The role of small-scale sediment topography for oxygen flux across the diffusive boundary layer, Limnol. Oceanogr., 47, 837-847, 2002.

Roy, H., Lee, J. S., Jansen, S., and de Beer, D.: Tide-driven deep pore-water flow in intertidal sand flats, Limnol. Oceanogr., 53, 1521-1530, 2008.

Rusch, A. and Huettel, M.: Advective particle transport into permeable sediments-evidence from experiments in an intertidal sandflat, Limnol. Oceanogr., 45, 525-533, 2000.

Russell, J. B. and Cook, G. M.: Energetics of bacterial growth: balance of anabolic and catabolic reactions, Microbiol. Rev., 59, 48-62, 1995.

Sandnes, J., Forbes, T., Hansen, R., Sandnes, B., and Rygg, B.: Bioturbation and irrigation in natural sediments, described by animal-community parameters, Mar. Ecol.-Prog. Ser., 197, 169$179,2000$.

Schlüter, M., Sauter, E. J., Andersen, C. E., Dahlgaard, H., and Dando, P. R.: Spatial distribution and budget for submarine groundwater discharge in Eckernforde Bay (Western Baltic Sea), Limnol. Oceanogr., 49, 157-167, 2004.

Tilch, E.: Oszillationen von Wattflächen und deren fossiles Erhaltungspotential (Spiekerooger Rückseitenwatt, südliche Nordsee), Ph.D. thesis, Universität Oldenburg, 2003.

Tromp, T. K., Van Cappellen, P., and Key, R. M.: A global-model for the early diagenesis of organic-carbon and organic phosphorus in marine-sediments, Geochim. Cosmochim. Ac., 59, 1259$1284,1995$.
Usbeck, R., Schlitzer, R., Fischer, G., and Wefer, G.: Particle fluxes in the ocean: Comparison of sediment trap data with results from inverse modeling, J. Marine Syst., 39, 167-183, 2003.

Valiela, I., Teal, J. M., Volkmann, S., Shafer, D., and Carpenter, E. J.: Nutrient and particulate fluxes in a salt marsh ecosystem: Tidal exchanges and inputs by precipitation and groundwater, Limnol. Oceanogr., 23, 798-812, 1978.

Voss, P. C. and van Kesteren, W. P.: The long-term evolution of intertidal mudflats in the northern Netherlands during the Holocene: natural and anthropogenic processes, Cont. Shelf Res., 20, 1687-1710, 2000.

Wetzel, A.: Ökologische und stratigraphische Bedeutung biogener Gefüge in quartären Sedimenten am NW-afrikanischen Kontinentalrand, Meteor Forschungsergebnisse, Reihe C: Geologie und Geophysik, 34, 1-47, 1981.

Whiting, G. J. and Childers, D. L.: Subtidal advective water flux as a potentially important nutrient input to southeastern USA saltmarsh estuaries, Estuar. Coast. Shelf S., 28, 417-431, 1989.

Wilber, R., Milliman, J., and Halley, R.: Accumulation of bank-top sediment on the western slope of Great Bahama Bank: Rapid progradation of a carbonate megabank, Geology, 18, 970-974, 1990.

Wilms, R., Kopke, B., Sass, H., Chang, T. S., Cypionka, H., and Engelen, B.: Deep biosphere-related bacteria within the subsurface of tidal flat sediments, Environ. Microbiol., 8, 709-719, 2006a.

Wilms, R., Sass, H., Köpke, B., Köster, J., Cypionka, H., and Engelen, B.: Specific Bacterial, Archaeal, and Eukaryotic Communities in Tidal-Flat Sediments along a Vertical Profile of several Meters, Appl. Environ. Microb., 72(4), 2756-2764, 2006b.

Wilms, R., Sass, H., Köpke, B., Cypionka, H., and Engelen, B.: Methane and sulfate profiles within the subsurface of a tidal flat are reflected by the distribution of sulfate-reducing bacteria and methanogenic archaea, Fems Microbiol. Ecol., 59, 611-621, 2007.

Wilson, A. M. and Gardner, L. R.: Tidally driven groundwater flow and solute exchange in a marsh: numerical simulations, Water Resour. Res., 42, W01405, doi:10.1029/2005WR004302, 2006.

Wirtz, K.: Control of biochemical cycling by mobility and metabolic strategies of microbes in the sediments: an integrated model study, Fems Microbiol. Ecol., 46, 295-306, 2003.

Yang, S. L., Ding, P. X., and Chen, S. L.: Changes in progradation rate of the tidal flats at the mouth of the Changjiang (Yangtze) River, China, Geomorphology, 38, 167-180, 2001.

Yang, S. L., Li, M., Dai, S. B., Liu, Z., Zhang, J., and Ding, P. X.: Drastic decrease in sediment supply from the Yangtze River and its challenge to coastal wetland management, Geophys. Res. Lett., 33, L06408, doi:10.1029/2005GL025507, 2006. 